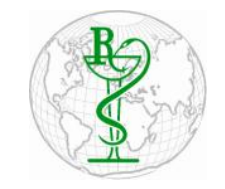

INDO GLOBAL JOURNAL OF

PHARMACEUTICAL SCIENCES

ISSN 2249- 1023

\title{
Ultraviolet Spectrophotometric Method Development and Validation for Estimation of Pesticide Dimethoate in Brassica oleracea
}

\author{
M. Sudha Rani, A. Shanta Kumari *, K. Praveen \\ Department of Pharmaceutical Analysis, Nirmala College of Pharmacy, Mangalagiri, Guntur, Andhra Pradesh, India
}

\begin{abstract}
Address for
Correspondance

A. Shanta Kumari,

Skatakam9@g

mail.com
\end{abstract}

Received:

26.04.2018

Accepted:

15.06.2018

\begin{abstract}
Indiscriminate use of pesticides in agriculture is concerned with the health of humans. Accumulation of residues in food and agricultural environment is risking ecological balance. Residues of dimethoate present in locally available variety Brassica oleracea commonly called as cauliflower were determined. A simple, sensitive, accurate and economical spectroscopic method has been developed for the estimation dimethoate in Brassica oleracea. An absorption maximum was found to be at $240 \mathrm{~nm}$ with the solvent methanol. Results of the analysis were validated for accuracy, precision, LOD, LOQ and were found to be satisfactory. The proposed method is simple, rapid and suitable for the routine quality control analysis. () 2018 iGlobal Research and Publishing Foundation. All rights reserved.

Cite this article as: Sudha Rani, M.; Kumari, A.S.; Praveen, K. Ultra Violet Spectrophotometric Method Development and Validation for Estimation of Pesticide Dimethoate in Brassica oleracea. Indo Global Journal of Pharmaceutical Sciences, 2018; 8(3): 104-107.
\end{abstract}

Keywords Dimethoate; Brassica oleracea.

\section{INTRODUCTION}

Dimethoate [1] is a widely used organophosphate insecticide and acaricide in agriculture. It was patented and introduced in the 1950s by American Cyanamid. Like other organophosphates, dimethoate is an acetylcholinesterase inhibitor which disables cholinesterase, an enzyme essential for central nervous system function. It acts both by contact and through ingestion. It is readily absorbed and distributed throughout plant tissues, and is degraded relatively rapidly. Dimethoate is used for apples, wheat, beans, grapes, pears, pineapples, plums, potatoes, tomatoes, lettuces, carrots, cauliflower .Various methods were available for the determination of dimethoate such as Gas chromatography-Mass spectrometry (GC/MS), HPLC-MS. A cheap, accurate and precise U.V method is developed for the determination of dimethoate in Brassica oleracea.

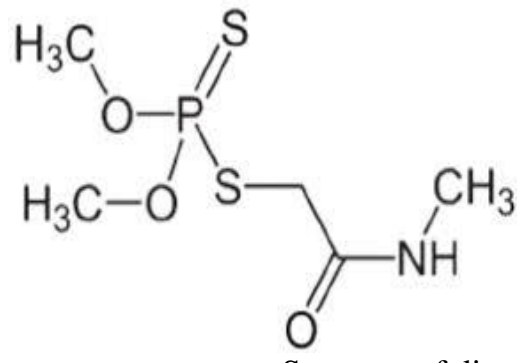

Structure of dimethoate:

Dimethoate IUPAC Name is $O, O$-dimethyl $S$-[2(methylamino)-2-oxoethyl]dithiophosphate,CAS number is 60-51-5.The Brand name is TAFGOR manufactured by Rallis India limited.

Cauliflower is one of the several vegetables in the species brassica oleracea belonging to the family brassicaceae. Cauliflower have been associated with its ability to help in cancer prevention. It provides the support for the antioxidants in the body, detoxification and anti-inflammatory effects. It is rich source of vitamin $\mathrm{C}$ and $\mathrm{K}$. 
Indo Global Journal of Pharmaceutical Sciences, 2018; 8(3): 104-107

The EPA (Environmental Protection Agency) tolerance level for dimethoate is 0.5 to $2 \mathrm{mg} / \mathrm{kg}$. If this limitation is crossed it may cause adverse effects like numbness, tingling sensations, in coordination, headache, dizziness, tremor, nausea, abdominal cramps, sweating, blurred vision, difficulty in breathing or respiratory depression and slow heart beat. Very high doses may result in unconsciousness and convulsion or fatality. Hence our project aims at detecting and quantifying, pesticide dimethoate present in brassica oleracea.

\section{INSTRUMENTATION:}

\begin{tabular}{|l|l|}
\hline Instrument name & Instrument I.D \\
\hline $\begin{array}{l}\text { U.V/Visible } \\
\text { spectrophotometer }\end{array}$ & $\begin{array}{l}\text { LAB Analytical 2000 U } \\
\text { ANDIA }\end{array}$ \\
\hline I.R Spectrophotometer & $\begin{array}{l}\text { BRUKER ALPHA } \\
\text { ECO-ATR }\end{array}$ \\
\hline
\end{tabular}

\section{MATERIALS:}

HPLC grade Methanol purchased from Merck (India) life sciences pvt.ltd. , Distilled water procured from Nirmalacollege of pharmacy, Atmakuru, Guntur district. Dimethoate $30 \%$ EC (Tafgor) manufactured by Rallis India ltd.

\section{METHOD DEVELOPMENT}

\section{Procedure for calibration curve:}

$1 \mathrm{ml}$ of dimethoate solution was pippeted into a $100 \mathrm{ml}$ volumetric flask and diluted with methanol to obtain $300 \mu \mathrm{g} / \mathrm{ml}$ solution. From this solution $1 \mathrm{ml}$ was taken and make up the volume to $100 \mathrm{ml}$ with Methanol. From the above solution aliquots of $0.1,0.2,0.3,0.4,0.5,0.6 \mathrm{ml}$ were taken and volume was made up to $10 \mathrm{ml}$ with Methanol to obtain concentrations of $30,60,90,120,150 \mu \mathrm{g} / \mathrm{ml}$. The calibration curve was constructed taking

ASSAY: For the estimation of dimethoate ${ }^{[3]} 3 \mathrm{gm}$ of sample procured from Mulapadu, Ibrahimpatnam (mandal), krishna dist. was crushed in a mixer separately. The homogenate was extracted with the solvent methanol and centrifuged for $10 \mathrm{~min}$ at $1000 \mathrm{rpm}$. The absorbance of sample was measured at 240 $\mathrm{nm}$ in U.V spectrophotometer.

\section{Assay result:}

The amount of dimethoate was found to be $\mathbf{0 . 1 m g}$ in $3 \mathrm{gm}$ of brassica oleracea (cauliflower $1 \mathrm{~kg}$ ) sample procured from and 33.3mg for the whole weight of brassica oleracea (cauliflower). The standard value according to Environmental protection agency (EPA) is 0.5 to $2 \mathrm{mg} / \mathrm{kg}$.

\section{FTIR STUDY DISCUSSIONS:}

FTIR studies were conducted for pesticide dimethoate and Brassica oleracea (Cauliflower). The characteristic peaks were identified. The presence of dimethoate was confirmed by the FTIR studies.

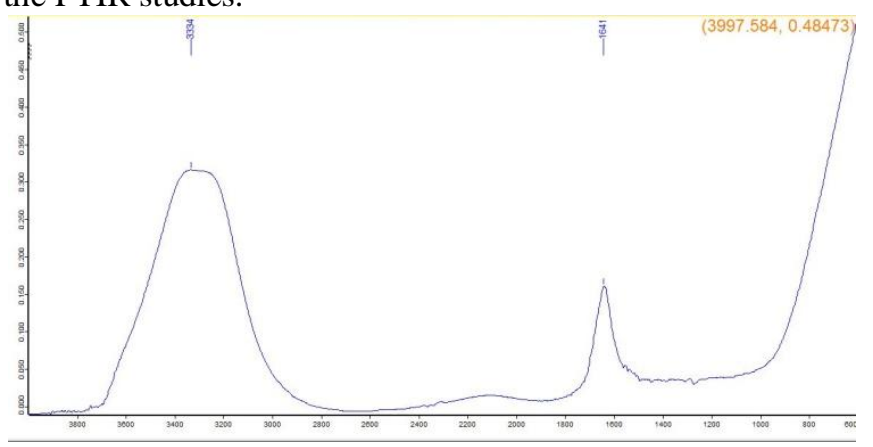

Fig no: 2 FTIR spectra for pesticide dimethoate

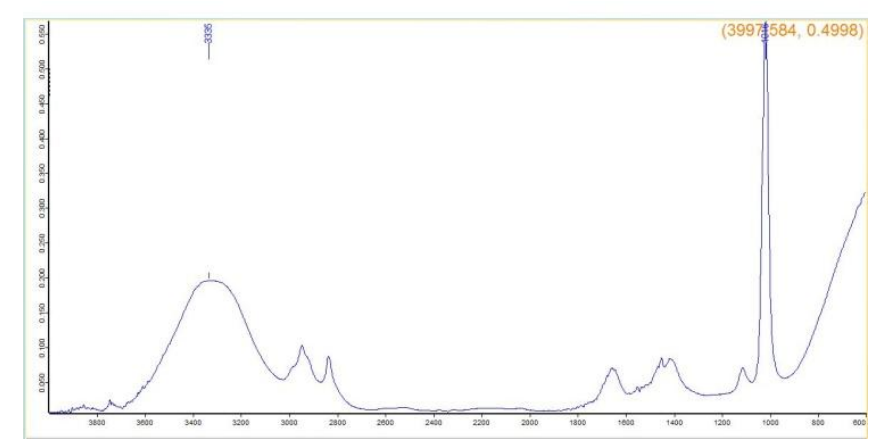

Fig no: 1 FTIR spectra for Brassica oleracea

\section{VALIDATION PARAMETERS:}

The UV spectrophotometric method was validated in accordance with ICH guidelines.

\section{Linearity:}

Fresh aliquots were prepared from stock solution ranging from $15 \mu \mathrm{g}$ to $210 \mu \mathrm{g} / \mathrm{ml}$. The samples were scanned in UV-Visible Spectrophotoeter using methanol as blank. The final concentration of each solution in $\mu \mathrm{g} / \mathrm{ml}$ was calculated and plotted against absorbance. The slope, y-intercept were calculated.

\section{Accuracy:}

Accuracy of the method confirmed by studying recovery at 3 different concentrations for 50,100 and $150 \%$ of these expected, in accordance with ICH guidelines, by replicate analysis. Standard drug solution was added to a pre analysed sample solution and percentage drug content was measured. The results from study of accuracy were reported.

\section{Precision:}

The precision of the analytical method was studied by analysis of multiple sampling of homogenous sample. The precision was expressed as standard deviation or relative standard deviation. Six independent test samples of dimethoate were taken and the absorbance was measured at $240 \mathrm{~nm}$.

\section{Robustness:}

Robustness of the proposed method was determined by analysis of aliquots from homogenous lots by different 
Indo Global Journal of Pharmaceutical Sciences, 2018; 8(3): 104-107

physical parameters like $\mathrm{pH}$, wavelength. This is evaluated by carrying out the six replicate samples of dimethoate at $240+$ $2 \mathrm{~nm}$. The relative standard deviation was found within the specified limits.

\section{LOD AND LOQ :}

LOD and LOQ were calculated by method based on the standard deviation $(\sigma)$ and slope of calibration curve using the formula

Where,

$$
\begin{aligned}
& \mathrm{LOD}=3.3 \sigma / \mathrm{S} \\
& \mathrm{LOQ}=10 \sigma / \mathrm{S}
\end{aligned}
$$

$\sigma=$ the standard deviation of the response

$\mathrm{S}=$ the slope of the calibration curve

The LOD and LOQ were calculated as per above formula

\section{Solution stability:}

The solution stability of dimethoate in diluents were determined by storing sample solutions in a tightly capped volumetric flask at room temperature for $24 \mathrm{hrs}$. the amount of dimethoate were measured at different time intervals like initial , 6, 24 and 48 hrs and the results were compared with the freshly prepared dimethoate solution.

\section{FORCED DEGRADATION STUDIES}

The specificity of the method was demonstrated through forced degradation studies conducted on the sample using acid, alkaline, oxidative, reductive degradations. The sample was exposed to these conditions and the absorbance was studied thus indicating that the method effectively separated the degraded products from the active pesticide. Regulatory guidelines ICH Q2A, Q2B, Q3B and FDA 21 CFR section 211 requires the development and validation of stabilityindicating potency assays.

\section{Acid degradation studies}

From the standard stock solution, $5 \mathrm{ml}$ was taken in $50 \mathrm{ml}$ volumetric flask, add $1 \mathrm{ml}$ of $5 \mathrm{~N} \mathrm{HCL}$ and heated at $70^{\circ} \mathrm{c}$ for 1 hour o a water bath. The flask was removed from the water bath and allowed to cool at room temperature. Add $1 \mathrm{ml}$ of $5 \mathrm{~N}$ $\mathrm{NaOH}$ to neutralize the solution cooled at room temperature and diluted to volume with diluent and mixed. The absorbance of the solution was measuredat $240 \mathrm{~nm}$.

\section{Alkali degradation studies}

From the standard stock solution, $5 \mathrm{ml}$ was taken in $50 \mathrm{ml}$ volumetric flask, add $1 \mathrm{ml}$ of $5 \mathrm{~N} \mathrm{NaOH}$ and heated at $70^{\circ} \mathrm{c}$ for 1 hour on a water bath. The flak was removed from the water bath and allowed to cool at room temperature. Add $1 \mathrm{ml}$ of $5 \mathrm{~N}$ HCL to neutralize the solution,cooled at room temperature and diluted to volume with the diluent and mixed up to the volume. The absorbance of the solution was measured at $240 \mathrm{~nm}$.

\section{Oxidation}

From the standard stock solution $5 \mathrm{ml}$ was taken in $50 \mathrm{ml}$ volumetric flask, add $1 \mathrm{ml}$ of $30 \% \mathrm{H}_{2} \mathrm{O}_{2}$ and heated at $70^{\circ} \mathrm{c}$ for $1 \mathrm{hr}$ on water bath. The flask was removed from the water bath and allowed to cool at room temperature and diluted to volume with diluent and mixed. The absorbance of the solution was measured at $240 \mathrm{~nm}$.

\section{Reduction}

From the standard stock solution $5 \mathrm{ml}$ was taken in $50 \mathrm{ml}$ volumetric flask, add $1 \mathrm{ml}$ of $10 \%$ sodium bisulphate and heated at $70^{\circ} \mathrm{c}$ for $1 \mathrm{hr}$ on water bath. The flask was removed from the water bath and allowed to cool at room temperature and diluted to volume with diluent and mixed. The absorbance of the solution was measured at $240 \mathrm{~nm}$.

\section{RESULTS AND DISCUSSIONS}

Calibration: Table 1:

\begin{tabular}{|l|l|l|}
\hline S.No & Concentration $(\mu \mathrm{g} / \mathrm{ml})$ & Absorbance at 240nm \\
\hline 01 & 30 & 0.2128 \\
\hline 02 & 60 & 0.3267 \\
\hline 03 & 90 & 0.4352 \\
\hline 04 & 120 & 0.5425 \\
\hline 05 & 150 & 0.6573 \\
\hline 06 & 180 & 0.7635 \\
\hline
\end{tabular}

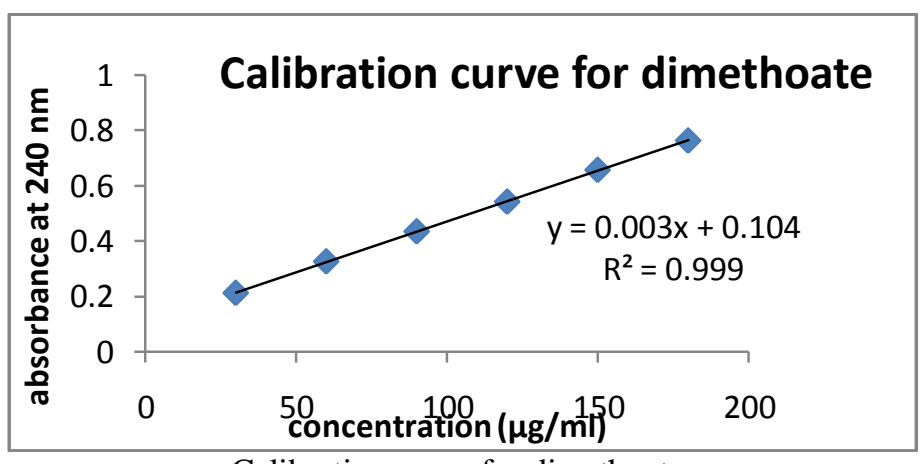

Calibration curve for dimethoate

Validation parameters:

Linearity:

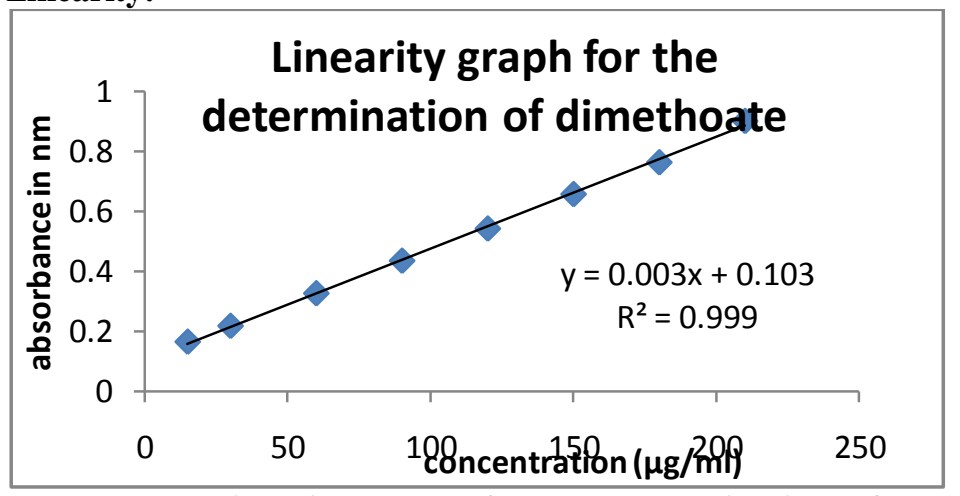

Fig no : 3 Linearity graph for the determination of dimethoate 
Indo Global Journal of Pharmaceutical Sciences, 2018; 8(3): 104-107

\begin{tabular}{|c|c|c|c|}
\hline S.NO & PARAMETER & \multicolumn{2}{|l|}{ RESULTS } \\
\hline 01 & $\begin{array}{l}\text { Linearity } \\
\text { Correlation } \\
\text { coefficient }\end{array}$ & \multicolumn{2}{|c|}{$\begin{array}{l}15 \mathrm{ppm}-210 \mathrm{ppm} \\
\mathrm{R}^{2}=0.999\end{array}$} \\
\hline 02 & Accuracy & \multicolumn{2}{|c|}{$\%$ Recovery $=100.13 \%$} \\
\hline 03 & Precision & \multicolumn{2}{|c|}{$\begin{array}{l}\text { Mean }=0.5474 \\
\text { S.D }=0.006 \\
\% \text { R.S.D }=1.09 \%\end{array}$} \\
\hline 04 & \multicolumn{3}{|l|}{ Robustness } \\
\hline & (i) $\mathrm{pH}$ & 5.0 & 5.4 \\
\hline & & $\begin{array}{l}\text { Mean }=0.4687 \\
\text { S.D }=0.0050 \\
\% \quad \text { R.S.D }= \\
1.066 \%\end{array}$ & $\begin{array}{l}\text { Mean } \\
0.4524 \\
\text { S.D } \\
0.00047 \\
\% \text { R.S.D }= \\
0.103 \%\end{array}$ \\
\hline & (ii)Wavelength & $238 \mathrm{~nm}$ & $242 \mathrm{~nm}$ \\
\hline & & $\begin{array}{l}\text { Mean }=0.6963 \\
\text { S.D }=0.0101 \\
\% \quad \text { R.S.D }= \\
1.45 \%\end{array}$ & $\begin{array}{l}\text { Mean } \\
0.6759 \\
\text { S.D } \\
\text { 0.00860 } \\
\text { \%R.S.D }= \\
1.272 \%\end{array}$ \\
\hline 05 & LOD \& LOQ & $185.4 \& 561$ & \\
\hline 06 & Solution stability & \multicolumn{2}{|l|}{ Stable upto $48 \mathrm{hrs}$} \\
\hline 07 & Acid degradation & \multicolumn{2}{|c|}{$\begin{aligned} \text { Mean } & =2.8156 \\
\text { S.D } & =0.0260 \\
\text { \% R.S.D } & =0.923 \%\end{aligned}$} \\
\hline 08 & $\begin{array}{l}\text { Alkali } \\
\text { degradation }\end{array}$ & \multicolumn{2}{|c|}{$\begin{aligned} \text { Mean } & =2.8448 \\
\text { S.D } & =0.0111 \\
\% \text { R.S.D } & =0.390 \%\end{aligned}$} \\
\hline 09 & $\begin{array}{l}\text { Oxidation } \quad \& \\
\text { Reduction }\end{array}$ & \multicolumn{2}{|c|}{$\begin{array}{l}\text { Not stable with oxidizing and } \\
\text { reducing agents }\end{array}$} \\
\hline
\end{tabular}

\section{CONCLUSION}

In the present investigation, new analytical method was developed for the estimation of dimethoate in Brassica oleracea using U.V Spectrophotometer. The presence of dimethoate was confirmed by FTIR studies. A simple, precise and robust method was developed for the estimation of pesticide dimethoate. It was concluded that high amounts of dimethoate residues were present in Brassica oleracea.

\section{ACKNOWLEDGEMENT}

The authors are thankful to Nirmala college of pharmacy, Mangalagiri, Guntur, Andhra Pradesh, India for providing necessary facilities to carry out the research work.

\section{REFERENCES:}

1. https://www.newport.com/n/introduction-to-ftirspectroscopy

2. Skoog, Douglas A.; Holler, F. James; Crouch, Stanley R. (2007). Principles of Instrumental Analysis (6th ed.). Belmont, CA: Thomson Brooks/Cole. pp. 169-173. ISBN 9780495012016.

3. Dauterman, W. C.; Viado, G. B.; Casida, J. E.; O'Brien, R. D. (1960). "Insecticide Residues, Persistence of Dimethoate and Metabolites Following Foliar Application to Plants". Journal of Agricultural and Food Chemistry. 8 (2): 115-9. doi: $10.1021 / \mathrm{jf} 60108 \mathrm{a} 013$

4. Padmasheela, N. C.; Delvi, M. R. (2004). "Effect of Dimethoate (Rogor 30\% EC) on the brain neurosecretory cells of third instar grubs of Oryctes rhinoceros L. (Coleoptera: Scarabaeidae)". Journal of environmental biology. 25 (4): 451-5. PMID 15907075.

5. https://www.ravensdown.co.nz/products/agrochemicals/r ogor $^{\text {[full citation needed }}$

6. http://www.ema.europa.eu/docs/en_GB/document_library /Scientific guideline/2009/09/WC500002662.pdf

7. Ana Masia.et.al., (2014):Liquid chromatography-mass spectrometry (LC-MS)

8. Sufang Fan.et.al., (2014) : multi residue method on a modified QUECHERS method

Indo Global Journal of Pharmaceutical Sciences( ISSN 22491023 ; UGC Journal No.: 44477; CODEN- IGJPAI; NLM ID: 101610675) indexed and abstracted in EMBASE(Elsevier), UGC Journal List, National Library of Medicine (NLM) Catalog, Elsevier( EMBASE), ResearchGate, Publons, CAS (ACS), Index Copernicus, Google Scholar and many more. For further details, visit http://iglobaljournal.com 